\title{
Resilience and emotional intelligence in athletes
}

Resiliência e inteligência emocional em atletas

\author{
Juliana Martinez Pieroni $^{\bullet}{ }^{\bullet}$, Cinthia de Souza Rodrigues ${ }^{\bullet}$, Cláudia Maria Nóbrega ${ }^{\bullet}$, Janaina de \\ Souto Mendonça ${ }^{\circ}$, Shirley Martins dos Santos Silva ${ }^{\circ}$, Maria do Carmo Fernandes Martins ${ }^{\circ}$, \\ Mirlene Maria Matias Siqueira ${ }^{\circ}$
} Universidade Metodista de São Paulo, São Bernardo do Campo, São Paulo, Brasil. *Autor para correspondência. E-mail:
jmpieroni@gmail.com

\begin{abstract}
Introduction: In contemporary society, Sport Psychology makes use of emotional intelligence and resilience constructs aiming at the better performance of athletes, both in personal fulfillment and in obtaining satisfactory results in competitions. Thus, the study aimed to verify the relationship between emotional intelligence and resilience of athletes. Material and methods: Methodology Study of a quantitative approach applied to 32 athletes from clubs and private universities, located in Greater ABC / State of São Paulo, Brazil. The data were collected with due ethical care, in relation to research with human beings, through the Informed Consent Form (CIF). For data collection, the Emotional Intelligence Measure (MIE) and the Resilience Scale were used, both validated in Brazil and with satisfactory precision indexes. As this is a quantitative study, descriptive statistical analyzes of emotional intelligence and resilience skills were performed, using the statistical package SPSS - Statistical Package for the Social Science, version 17.0 for Windows. Results and discussion: The results brought evidence that the intrapsychic ability of emotional intelligence, called self-awareness, was the one most related to the athletes' resilience. Such results suggest that the more the athlete increases his ability to read, organize and name his own emotions, the greater his chances of being resilient, increasing his ability to adapting to and tolerating suffering, in the face of adverse situations and pressures, often experienced during sports practice. Final considerations: It seems that athletes with well-developed self-awareness skills would also be those who would tend to become more resilient, reaffirming the importance of Positive Psychology postulates in determining new horizons for research in the areas of Humanities and Social Sciences, especially those that emphasize strengths and weaknesses positive virtues of people.
\end{abstract}

Keywords: emotional intelligence, resilience, athletes.

Resumo: Introdução: Na sociedade contemporânea, a Psicologia do Esporte faz uso de construtos de inteligência emocional e resiliência visando o melhor desempenho dos atletas, tanto na realização pessoal quanto na obtenção de resultados satisfatórios em competições. Assim, o estudo teve como objetivo verificar a relação entre inteligência emocional e resiliência de atletas. Material e métodos: Metodologia Estudo com abordagem quantitativa aplicada a 32 atletas de clubes e universidades privadas, localizados no Grande ABC / Estado de São Paulo, Brasil. Os dados foram coletados com os devidos cuidados éticos, em relação à pesquisa com seres humanos, por meio do Termo de Consentimento Livre e Esclarecido (CIF). Para a coleta de dados, foram utilizadas a Medida de Inteligência Emocional (MIE) e a Escala de Resiliência, ambas validadas no Brasil e com índices de precisão satisfatórios. Por se tratar de um estudo quantitativo, foram realizadas análises estatísticas descritivas da inteligência emocional e habilidades de resiliência, utilizando o pacote estatístico SPSS - Statistical Package for the Social Science, versão 17.0 para Windows. Resultados e discussão: Os resultados trouxeram evidências de que a habilidade intrapsíquica de inteligência emocional, denominada autoconsciência, foi a que mais se relacionou com a resiliência dos atletas. Tais resultados sugerem que quanto mais o atleta aumenta sua capacidade de ler, organizar e nomear suas próprias emoções, maiores suas chances de ser resiliente, aumentando sua capacidade de se adaptar e tolerar o sofrimento, diante de situações adversas e pressões, muitas vezes vivenciadas. durante a prática esportiva. Considerações finais: Parece que atletas com autoconsciência bem desenvolvida seriam também aqueles que tenderiam a se tornar mais resilientes, reafirmando a importância dos postulados da Psicologia Positiva na determinação de novos horizontes para pesquisas nas áreas de Humanidades e Ciências Sociais, especialmente aqueles que enfatizam os pontos fortes e fracos, virtudes positivas das pessoas.

Palavras-chave: inteligência emocional, resiliência, atletas. 


\section{Introduction}

It is believed that one of the main goals of athletes is to develop their own skills to increase their commitment and sports performance (Weinberg, 2013; Lemos et al., 2017). However, in an emotionally charged environment, there is no doubt that athletes need to firmly consolidate their adaptive capacities to deal with healthy living habits fully in physical, cognitive and social ways (Galanti et al., 2014; Hernández-Mendo et al., 2019)

Coping with challenging situations in a positive way can bring potential health benefits and fitness training plays an important role in preventing stress-related problems in sports, a characteristic of individuals in a resilient process (Merkel, 2013; Codonhato et al., 2018).

From this point, there has been a lot of interest in understanding the relationship of variables within sports performance, and in the process of obtaining resilient qualities referred to in the literature in order to improve psychological capacities in adverse situations, potentially avoiding undesirable aspects of the training process. Stress, such as muscle stiffness, tension and decreased attention and focus (Codonhato et al., 2018; Stults-Kolehmainen \& Sinha, 2014).

However, in addition to the psychological aspects involved in sports performance, success in sport is usually associated with emotionally intelligent athletes who work in the effective zone of their emotions, which justify psychology being considered a science applied to sport and having the professional psychologist working with the behavioral and cognitive components that influence the performance of an athlete between the skills of emotional intelligence and resilience in the path of self-perception, self-control, self-motivation, modeling and social practices (Kopp \& Jekauc, 2018; Rose Júnior, 2000).

In this sense, the present study seeks to verify the relationship between emotional intelligence and the resilience of athletes as a development of exercise in relation to individual and collective attitudes. In addition, it seeks to demonstrate the correlation indices between the five emotional intelligence skills and resilience.

\section{Material and methods}

Study of a quantitative approach applied to 32 athletes from clubs and private universities, located in Greater ABC/São Paulo State, Brazil. Instruments used - Emotional Intelligence Measurement Scale (MIE), unifactorial Resilience Scale designed based on the use of the Bar-On EQ-i questionnaire (Bar-On, 2006), which, through clear and self- report questions, measures the quotient emotional state of a questioned individual. As an inclusion criterion, participants should be at least 1 year in a sport and still practicing. The exclusion criteria were: failure to complete the BarOn EQ-i: YV questionnaire or failure to complete it; refuse to answer the questionnaire.

\section{Emotional Intelligence Measurement Scale}

Scale developed and validated by Siqueira e Barbosa (1999) with precision indexes between 0.78 and 0.87 , assess the skills of Emotional Intelligence through 59 items distributed in five factors:

I Self-awareness - 10 items, $\alpha=0.74$, which describe introspective actions to recognize, evaluate, reflect, name and identify feelings;

II Self-motivation - 12 items, $\alpha=0.82$, which assess the ease of drawing up plans for life, in order to create, believe, plan, persist and maintain situations conducive to achieving future goals, and remain optimistic about the future;

III Self-control - 10 items, $\alpha=0.84$, which verify the ease of managing one's own feelings, impulses, thoughts and behaviors.

IV Empathy - 14 items, $\alpha=0.87$. This factor refers to the ease of identifying the feelings, desires, intentions, problems, motives and interests of others, through reading and understanding verbal and nonverbal behaviors;

$\mathrm{V} \quad$ Sociability - 13 items, $\alpha=0.82$, which describes the ease of starting and preserving friendships, of being accepted by people, of valuing social relationships, of adapting to new situations, leading, coordinating and guiding the actions of other people.

\section{Single factor resilience scale}

Composed of 10 items, $\alpha=0.85$ being a five-point response scale, $(0$-never is true and 4 - is always true). 
In the analysis of the correlation indices between the five emotional intelligence skills and resilience, the values indicated by Bisquerra were adopted; Sarriera; Martinez (2004), as follows: 1 - perfect correlation, 0.80 $<\mathrm{r}<1$ - very high correlation, $0.60<\mathrm{r}<0.80$ - high correlation, $0.40<\mathrm{r}<0.60$ - moderate correlation, $0.20<\mathrm{r}$ $<0.40$ - low correlation, $0<\mathrm{r}<0.20$ - very low correlation, $\mathrm{r}=0$ - null correlation. In addition, at a starting point, it was possible to observe that Cronbach's Alpha values approached 1, indicating that the precision measure of the scales used in the study was good, thus giving statistical credibility to the correlations performed.

\section{Protocol followed and proposed by Bar-On}

a) Ensure that each individual has a pencil or pen; b) Allow participants to feel comfortable and relaxed through pleasant conversation; c) Explain the objectives of the instrument and the research; d) Read and clarify the instructions at the beginning of the instrument and the possibilities for answers; e) At the end of the application, verify that the subject answered all sixty questions.

At the end of the questionnaire, questions were added to characterize the sample, with regard to: sex; age; sport modality and category; schooling, marital status and length of stay in the team. The first stage of the research consisted of the request and consent of the technicians responsible for the sports teams, for authorization of data collection. Soon after, the teams of researchers went to the combined days and locations to conduct data collection at the teams' training sites. After a brief presentation of the objectives, all athletes consented to participate and the research and the research team delivered and collected the Free and Informed Consent Term (ICF) and later distributed the material to be answered. In cases where the young person was under 18, it was requested that the (ICF) be signed by those responsible, in order to respect the ethical aspect of research with human beings.

\section{Sample}

Sample consisting of athletes $(\mathrm{N}=32)$ who work in professional teams, $46.90 \%$ for one year, and $31.30 \%$, two years ago, in the cities that make up the Greater ABC, State of São Paulo. All athletes are male, with an average age of 20.84 years (SD = 5), mostly single (84.40\%), with $46.90 \%$ from high school and $37.50 \%$ from higher education incomplete. The predominant sport practiced is basketball $78.10 \%$, and most athletes belong to the youth category, $65.60 \%$. The data were collected in private clubs and universities, located in $A B C$ Paulista, São Paulo, Brazil.

\section{Data analysis}

As this is a quantitative study, data analysis was performed using the statistical package SPSS - Statistical Package for the Social Science, version 17.0 for Windows. Descriptive statistical analyzes of the variables (frequencies, percentages, means, standard deviations and correlation coefficients) were performed to describe and analyze the relationships between emotional intelligence and resilience skills. To analyze the variables, an ANOVA was performed, analysis of variance used to compare the means (inter and intravariability) of more than two groups, in the case of athletes from the youth category and adults, simultaneously.

\section{Results}

Here we present the results obtained in the analysis of the youth $(n=21)$ and adult $(n=11)$ categories. In the speeches of the athletes we describe the skills divided into the youth and adult category. In the youth category, emotional intelligence skills on a 1 to 4 response scale, ranged from 2.60 (self-control) to 3.23 (selfmotivation), in the adult category, emotional intelligence skills on a 1 to 4 scale, vary from 2.80 (empathy) to 3.36 (self-motivation). Differences between the mean scores of emotional intelligence and resilience skills of youth and adult athletes are described in table 1.

Table 2 shows the correlation index between the five emotional intelligence skills and resilience in youth athletes $(n=21)$. The results show that the dimensions of emotional intelligence are not significantly related to resilience. Items on the scale are heterogeneous. Verification performed on a significant level of 0.05 and on Cronbach's Alpha values described on the diagonal and correlation matrix (Pearson's r). 
Table 1. Average scores of emotional intelligence and resilience skills of youth and adult athletes.

\begin{tabular}{cccccc}
\hline \multirow{2}{*}{ Variables } & \multicolumn{2}{c}{ Youth Category } & \multicolumn{2}{c}{ Adult Category } & \multirow{2}{*}{ F } \\
\cline { 2 - 5 } & $\mathrm{M}$ & $\mathrm{DP}$ & $\mathrm{M}$ & $\mathrm{DP}$ & \\
\hline Sociability & 3,02 & 0,29 & 2,99 & 0,48 & 0,035 \\
Empathy & 2,69 & 0,36 & 2,80 & 0,50 & 0,467 \\
Self motivation & 3,23 & 0,28 & 3,36 & 0,39 & 1,118 \\
Self control & 2,60 & 0,41 & 2,86 & 0,37 & 3,226 \\
Self-awareness & 3,04 & 0,37 & 3,29 & 0,41 & 2,961 \\
Resilience & 3,88 & 0,44 & 4,13 & 0,33 & 2,524 \\
\hline
\end{tabular}

*M - Mean, SD - Standard deviation, F - Test F*/variance ratios

Table 2. Correlation Matrix (Pearson's r) between the five emotional intelligence and resilience skills, youth category.

\begin{tabular}{ccccccc}
\hline Variables & $\mathbf{1}$ & $\mathbf{2}$ & $\mathbf{3}$ & $\mathbf{4}$ & $\mathbf{5}$ & $\mathbf{6}$ \\
\hline Sociability & 0,85 & & & & & \\
Empathy & $-0,05$ & 0,90 & & & & \\
Self motivation & 0,15 & 0,20 & 0,88 & & & \\
Self control & $0,43^{*}$ & $-0,05$ & 0,15 & 0,78 & & \\
Self-awareness & 0,12 & 0,32 & 0,19 & 0,07 & 0,79 & \\
Resilience & 0,10 & 0,41 & 0,33 & 0,14 & 0,15 & 0,85 \\
\hline
\end{tabular}

Table 3 shows the correlation index between the five emotional intelligence skills and resilience in adult athletes. The results inform, different correlations of the youth category, the results of the adult category ( $\mathrm{n}$ $=11)$, reveal a positive and significant correlation $\left(r=0.75^{*} ; 0.60<r<0.80\right)$ between the ability of emotional intelligence self-awareness and resilience. Verification performed at a significant level of 0.05 and Cronbach's Alpha values described on the diagonal and correlation matrix (Pearson's r).

Table 3. Correlation matrix between the five skills of emotional intelligence and resilience, adult category.

\begin{tabular}{ccccccc}
\hline Variables & $\mathbf{1}$ & $\mathbf{2}$ & $\mathbf{3}$ & $\mathbf{4}$ & $\mathbf{5}$ & $\mathbf{6}$ \\
\hline Sociability & 0,85 & & & & & \\
Empathy & 0,57 & 0,90 & & & & \\
Self motivation & 0,28 & 0,32 & 0,88 & & & \\
Self control & $-0,51$ & $-0,21$ & $-0,05$ & 0,78 & & \\
Self-awareness & 0,13 & 0,60 & $0,64^{*}$ & 0,10 & 0,79 & \\
Resilience & 0,21 & 0,56 & 0,58 & 0,14 & $0,75^{* * *}$ & 0,85 \\
\hline
\end{tabular}

\section{Discussion}

The most developed skill among athletes in the youth category is self-motivation and the least developed is self-control. The data suggest that young athletes, being in the full stage of development, and motivated by the prospect of the future, end up, having among all the skills of emotional intelligence, highlighted in the ability to motivate themselves and persist in the face of frustrations; controlling impulses and postponing satisfaction; regulate one's state of mind and prevent affliction from invading the ability to think; empathize and wait. The low index in the ability of self-control (average 2.60), can be influenced according to what they point out Santos \& Shigunov (2000) about the athletes, in the activity of high degree of pressure, in the competitions and in the training that precedes them, generating physical and emotional stress. In addition to charging for results in competitions, both from the club to which he is linked and from himself, there is also a charge for this athlete to produce results and meet the expectations of an incalculable contingent of fans.

In the category of adult athletes, the results suggest that the most developed skill among athletes in the adult category is also self-motivation, the least developed is empathy. It seems that the athletes, regardless 
of the category (youth and adults), had a higher average in the self-motivation ability, which may indicate that this is a factor influenced not by the age of the athlete, but rather, by the characteristic of the sports practice, which according with Garganta (2002) is characterized by seeking and perfecting the tasks to be performed with greater performance through technique, in sports games (confrontation between two individual or collective opponents).

With regard to resilience, on a response scale of 1 to 5 , the results suggest that athletes in the adult category have a higher average resilience (4.13) than athletes in the youth category (3.88). However, based on the criteria adopted by Bisquerra et al. (2004) it is possible to notice that in the "juvenile" group, the correlation between empathy emotional intelligence skills and resilience, obtained a moderate correlation index. In this case, one can raise the hypothesis that the correlation index has been compromised, due to the low number of research participants. It is suggested to increase the number of participants in order to observe whether new statistically significant correlations may arise, especially with regard to the ability to empathize and resilience.

The data seems to suggest that the resilience capacity in adults may be related to the introspective actions of recognizing, evaluating, reflecting, naming and identifying feelings, which are behavioral and cognitive components that influence an athlete's performance and that relate to skills emotional intelligence and resilience as self- perception (the athlete's ability to know himself in terms of his behaviors in relation to his life, social and professional situations, in addition to his relationship with himself). In addition to other factors, such as: Self-control (ability to manage one's emotions, mood and good mood); Self-motivation (the athlete's ability to motivate himself to perform his duties, regardless of the circumstances of the game, competitions, his personal life and other factors that may interfere with his performance; Modeling (ability to continually learn new sports skills, through observation and training of models of behaviors and competencies of other athletes) and social practices (interpersonal and teamwork skills).

From this point, as it is a new concept in the field of Psychology, it is worth remembering that resilience has been widely discussed from the theoretical and methodological point of view by the scientific community, but that some must be considered present in the development of any human being. Starting from the idea that the participants in this research are athletes, we must take into account the contributions of Santos \& Shigunov (2000) that some athletes can naturally develop a more consistent emotional structure, benefited by a favorable family formation, in addition to other factors that influence his personality. On the other hand, other athletes, on the other hand, will not live with such pressure and end up having their performance impaired due to the emotional pressure they are subject to. In addition, the results seem to corroborate the studies by Kerkoski (2009), that contemporary society in Sports Psychology makes use of emotional intelligence and resilience constructs aiming at the best performance of its athletes, both personally and in the obtaining satisfactory results in competitions.

Finally, an analysis of variance (ANOVA) showed that "there are no significant differences between the observed averages". This means that there are no differences between groups and individual differences within each group.

\section{Final considerations}

In athletes, evidence shows that the intrapsychic ability of emotional intelligence, self- awareness, that is, the recognition of one's emotions, is the one most related to resilience. Therefore, it is suggested that the more the athlete increases his ability to read, organize and name his own emotions, the greater his chances of being resilient, increasing his ability to adapt and tolerate suffering in the face of adverse and pressure situations that often sports practice provides. In this way, sports practice contributes to the development and improvement of characteristics related to resilience and emotional intelligence, to athletes, fulfilling a role of promoting health. This fact, which reaffirms the importance of the Psychology movement, in determining new horizons for research in the areas of human and social sciences. As a point of the Research Agenda, we also pointed out the need for further studies in order to observe whether new correlations that may arise between the skills of emotional intelligence and resilience, especially with regard to the ability to empathize and resilience, due to the fact, in this study, a moderate correlation index, although not significant.

\section{References}

Bar-On, R. 2006. The Bar-On model of emotional-social intelligence (ESI). Psicothema, 18, 13-25. 
Bisquerra, R., Sarriera J. C., \& Martínez, F. 2004. Introdução à estatística: enfoque informático com o pacote estatístico SPSS. Porto Alegre: Artmed.

Codonhato, R., Vissoci, J. R. N., Nascimento Júnior, J. R. A., Mizoguchi, M. V., \& Fiorese, L. 2018. Impact of resilience on stress and recovery in athletes. Revista Brasileira de Medicina do Esporte, 24(5), 352-356.

Galanti, G., Stefani, L., Scacciati, I., Mascherini, G., Buti, G., \& Maffulli, N. 2014. Eating and nutrition habits in young competitive athletes: a comparison between soccer players and cyclists. Translational Medicine @UniSa, 11, 44-47. Erratum in: Translational Medicine UniSa. 2015, 12, 1-3.

Garganta, J. 2002. O treino da tática e da técnica nos jogos desportivos à luz do compromisso cognição acção. In: Amadio, A. C., Barbanti, V. J., Bento J. O., Marques, A. T., (orgs) Esporte e atividade física: interação entre rendimento e saúde. São Paulo: Ed. Manole.

Hernández-Mendo, A., Reigal, R. E., López-Walle, J. M., ... \& Falco, C. 2019. Physical Activity, Sports Practice, and Cognitive Functioning: The Current Research Status. Frontiers in Psychology, 10, 2658.

Kerkoski, M. J. 2009. Prática desportiva e inteligência emocional: estudo da influência do desporto na aquisição de aptidões e competências da inteligência emocional. Tese (Doutorado) - Instituto de Estudos da Criança (ramo de conhecimento em Educação Física, Lazer e Recreação), Universidade do Minho, Portugal.

Kopp, A., \& Jekauc, D. 2018. The influence of emotional intelligence on performance in competitive sports: a meta-analytical investigation. Sports (Basel Switzerland), 6(4), 175.

Lemos, C. F. S., Santos, D. R., \& Soares, N. M. M. 2017. Physical fitness related to sportive performance in artistic gymnastics. Revista Brasileira de Cineantropometria e Desempenho Humano, 19(6), 743-750.

Merkel, D. L. 2013. Youth sport: positive and negative impact on young athletes. Open Access Journal of Sports Medicine, 4, 151-160

Rose Junior, D. 2000. O esporte e a psicologia: enfoque do profissional do esporte. In Rubio, K. (org.) Psicologia do esporte: interfaces, pesquisa e intervenção. São Paulo: Casa do Psicólogo.

Santos, S. G., \& Shigunov, S. 2000. Suporte psicológico ao atleta: uma necessidade “teórica” que precisa ser aplicada. Revista Treinamento Desportivo, 5(2), 74-83.

Siqueira, M. M. M., \& Barbosa, N. C. A. 1999. Matianny ThyssenConstrução e validação fatorial de uma medida de inteligência emocional. Psicologia: Teoria e Pesquisa, 15(2), 143-152.

Stults-Kolehmainen, M. A., \& Sinha, R. 2014. The effects of stress on physical activity and exercise. Sports Medicine, 44(1), 81-121.

Weinberg, R. S. 2013. Goal setting in sport and exercise: research and practical applications. Revista da Educação Física/UEM, 24(2), 171- 179.

\section{Minicurrículo}

Juliana Martinez Pieroni. Graduação em Psicologia (2009) pela Universidade Metodista de São Paulo, sendo bolsista de Iniciação Científica do CNPq (de 2005 a 2008). Mestrado em Psicologia da Saúde (2012), pela UMESP, bolsista CAPES, com realização de Intercâmbio para a Universidade do Algarve em Portugal (acordo bilateral entre as Universidades). Realização de Intercâmbio para o Canadá e Londres para aprimoramento da língua Inglesa. Atualmente é professora convidada na Universidade Presbiteriana Mackenzie, nos cursos de Pós-Graduação do Centro de Ciências Sociais e Aplicadas (CCSA) na modalidade presencial (desde 2013) e EAD (desde 2016) como curadora da disciplina Gestão de Pessoas e professora desta disciplina e outras disciplinas dos cursos de Gestão Estratégica de Pessoas, Liderança e Desenvolvimento Humano; Gestão Estratégica de Negócios, Gestão Estratégica de Serviços, e Gestão de Processos em Ambientes Corporativos. Durante o período de 7 anos na Universidade Metodista de São Paulo (UMESP) teve vivência em diversas frentes de atuação: Coordenadora do curso de Pós-Graduação em Gestão Estratégica de Pessoas e Psicologia Organizacional; Professora e Supervisora de estágio da Graduação em Psicologia; Orientadora de TCC (cursos presenciais e EAD); Membro de bancas de TCC (cursos presenciais e EAD). No EAD teve experiência em ministrar aulas virtuais (ao vivo e gravada), elaborar planejamento de aulas e materiais pedagógicos de disciplinas, realizar mediação pedagógica nos ambientes virtuais de aprendizagem Moodle e Blackboard Collaborate, interagindo com os alunos de forma síncrona e assíncrona, por meio de fóruns, chats, podcasts e avatares (ferramenta VOKI). Possui experiência profissional na área de Gestão de Pessoas e na área da Psicologia da Saúde, há mais de 11 anos, realizando atendimento psicológico, para adultos e crianças. 
Cinthia de Souza Rodrigues. Mestranda em Psicologia da Saúde, Universidade Metodista de São Paulo. Especialização em Psicologia Clínica Analítica, Centro Universitário Salesiano de São Paulo (2009). Graduação em Psicologia, Centro Universitário Salesiano de São Paulo (2006).

Cláudia Maria Nóbrega. Mestranda em Psicologia da Saúde, Universidade Metodista de São Paulo-UMESP. Especialização em violência na área da infância e juventude (LACRI IP USP), Graduação em Psicologia pela Universidade São Marcos (1995).

Janaina de Souto Mendonça. Mestrado em Psicologia da Saúde pela Universidade Metodista de São PauloUMESP (2012). Especialização em Terapia Comportamental pela Universidade de São Paulo (USP), e em Saúde Pública e Programa de Saúde da Família pela FACINTER. Graduação em Psicologia pela Universidade Estadual da Paraíba- UEPB (2003).

Shirley Martins dos Santos Silva. Mestrado em Psicologia da Saúde pela Universidade Metodista de São Paulo-UMESP (2011). Especialização em Cinesiologia Psicológica pelo Instituto Sedes Sapientiae (1998), Especialização em Psicologia da Saúde pela Universidade Metodista de São Paulo-UMESP (2011). Graduação em Psicologia pela Universidade Paulista (1990).

Maria do Carmo Fernandes Martins. Graduada em Psicologia pela Universidade de São Paulo (1977), Especialista em Psicodrama pela Sociedade de Psicodrama de Ribeirão Preto (1979), Mestre em Psicologia pela Universidade de Brasília (1984) e Doutora em Psicologia pela Universidade de Brasília (1999). Pesquisadora, assessora e parecerista da Fundação de Amparo à Pesquisa do Estado de São Paulo - FAPESP. Professora Associada aposentada da Universidade Federal de Uberlândia. Professora Titular da Universidade Metodista de São Paulo. Implantou e coordenou (2003-2008) o Programa de Pós-graduação em Psicologia da Universidade Federal de Uberlândia. Coordena o Programa de Pós-graduação em Psicologia da Saúde da Universidade Metodista de São Paulo desde 2016. Membro de GT ANPEPP. Possui experiência em Psicologia Organizacional e do Trabalho, Comportamento Organizacional e Psicologia da Saúde, investigando os seguintes temas: medidas em psicologia, satisfação no trabalho, bases de poder social, resiliência no trabalho, conflitos intragrupais, clima organizacional, bem-estar no trabalho, autoeficácia e engajamento no trabalho.

Mirlene Maria Matias Siqueira. Graduação (1974), Mestrado (1978), Doutorado (1995) em Psicologia pela Universidade de Brasília. Pós-doutorado (2010) como docente visitante na Universidade de Coimbra no Mestrado em Psicologia Organizacional e do Trabalho (WOP-P) do Programa Erasmus Mundus. Presidente da Comissão Organizadora do IV CBPOT.Experiência docente e de pesquisa em: construção e validação de medidas, bem-estar no trabalho, suportes social e organizacional, comportamento organizacional, inteligência emocional. Bolsista de Produtividade de Pesquisa do CNPq (2005 a 2014). Docente aposentada pela Universidade Federal de Uberlândia.

Como citar: Pieroni, J.M., Rodrigues, C.S., Nóbrega, C.M., Mendonça, J.S., Silva, S.M.S., Martins, M.C.F., \& Siqueira, M.M.M. 2021. Resilience and emotional intelligence in athletes. Pubsaúde, 6, a143. DOI: https://dx.doi.org/10.31533/pubsaude6.a143

Recebido: 6 mar. 2021.

Revisado e aceito: 25 mar. 2021.

Conflito de interesse: os autores declaram, em relação aos produtos e companhias descritos nesse artigo, não ter interesses associativos, comerciais, de propriedade ou financeiros que representem conflito de interesse.

Licenciamento: Este artigo é publicado na modalidade Acesso Aberto sob a licença Creative Commons Atribuição 4.0 (CC-BY 4.0). 